C.

11.60/2:

5

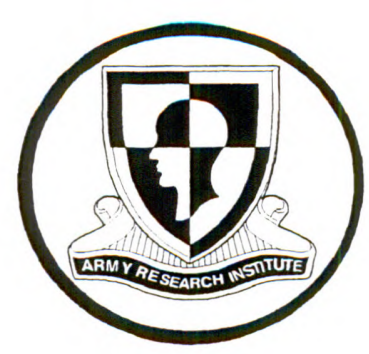

U.S. Army Research Institute

for the Behavioral and Social Sciences

Research Report 1805

\title{
Training the Troops: What Today's Soldiers Tell Us About Training For Information-Age Digital Competency
}

\author{
Brooke B. Schaab \\ J. Douglas Dressel \\ U.S. Army Research Institute
}

May 2003

US Govt. Document

Doc Ex

Approved for public release; distribution is unlimited. 